
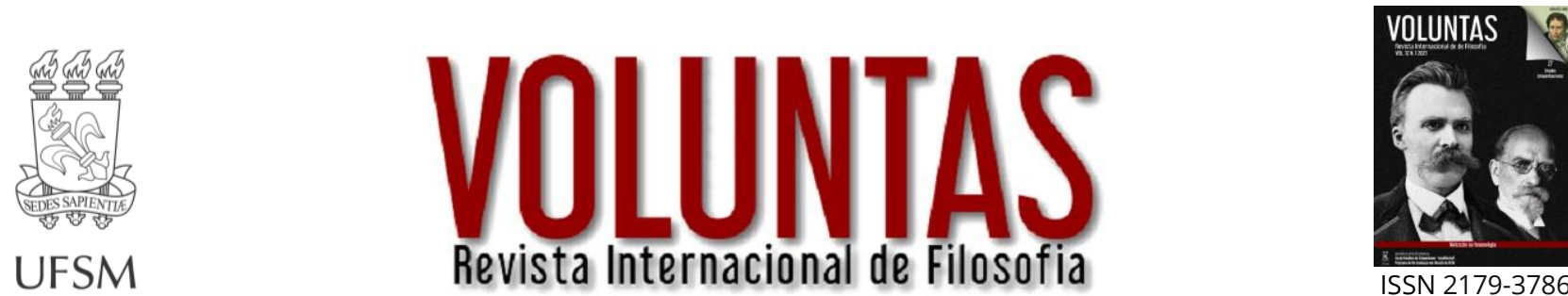

ISSN 2179-3786

๖Acesso aberto

Voluntas, Santa Maria, v.12, n.1, p. 01-26, jan/abril, 2021 • https://doi.org/10.5902/2179378664488

Submissão: 28/02/2021 • Aprovação: 05/04/2021 • Publicação: 30/04/2021

Nietzsche na fenomenologia

\title{
A interpretação heideggeriana sobre o eterno retorno de Nietzsche e a questão do tempo
}

\author{
Heidegger's interpretation of Nietzsche's eternal return and the question \\ of time
}

Newton Pereira Amusquivar Júnior 1 (1)

' Universidade Estadual de Campinas, Campinas, São Paulo (UNICAMP)

\section{RESUMO}

O objetivo do artigo é analisar a interpretação de Heidegger sobre o eterno retorno de Nietzsche, colocando como questão central a problemática do tempo. Para Heidegger, o filósofo de Zaratustra continua sendo metafísico, mas nele se constitui também o acabamento da metafísica. O eterno retorno tem importância fundamental nesse fim da metafísica, pois pensando o instante como algo eterno, se suprime a metafísica por dentro. Nas preleções de Nietzsche I, a interpretação sobre o eterno retorno se interliga com esse fim da metafísica e inversão do platonismo. Com isso, se revela uma concepção de tempo contrária à metafísica. Por outro lado, na década de 1950, em Quem é Zaratustra de Nietzsche? e a preleção O que significa pensar?, Heidegger aprofunda mais a interpretação do eterno retorno e de tempo, vendo na filosofia nietzschiana não só o acabamento da metafísica, mas também a possibilidade da passagem ao poético.

Palavras-chave: Nietzsche; Heidegger; Eterno retorno; Tempo

\begin{abstract}
The objective of the paper is to analyze Heidegger's interpretation of Nietzsche's eternal return, placing the issue of time as a central problem. For Heidegger, the philosopher of Zarathustra continues to be metaphysical, but it also constitutes the finishing of metaphysics. The eternal return has fundamental importance in this end of metaphysics, since thinking the instant as eternal, metaphysics is suppressed from within. In the lectures by Nietzsche I, the interpretation of the eternal return is intertwined with this end of metaphysics and inversion of Platonism, thereby revealing a conception of time contrary to metaphysics. On the other hand, in the 1950s, in Who is Nietzsche's Zarathustra? and the lecture What does it mean to think?, Heidegger expands further into the interpretation of the eternal return and time, seeing in nietzschean philosophy not only the finish of metaphysics, but also the possibility of the passage to the poetic.
\end{abstract}

Keywords: Nietzsche; Heidegger; Eternal return; Time 
A interpretação de Heidegger sobre a filosofia nietzschiana foi muito profunda e percorreu décadas. É natural, portanto, que ela sofra mudanças com o tempo, tal como no começo de seus estudos foram privilegiados os fragmentos póstumos (principalmente os que compuseram o livro $A$ vontade de poder) e depois, na década de 50 Assim falou Zaratustra passa a ter uma posição mais central. Além disso, é preciso destacar que Heidegger não é mero interprete de Nietzsche, mas é um filósofo que pensa com Nietzsche e, até mesmo por isso, contra ele, havendo nessa interpretação uma Auseinandersetzung, palavra esta que em alemão literalmente significa discussão, debate, disputa, em suma, é um "acerto de contas" entre filósofos. Desse longo "acerto de contas", Heidegger não sai o mesmo de antes, apesar de pensar a filosofia de Nietzsche de maneira crítica. Nesse sentido, Müller-Lauter afirma que "o pensamento de Heidegger se movimenta em uma proximidade peculiar à filosofia de Nietzsche também lá ainda onde se distancia disto"1.

Assim, dessa ambivalência de Heidegger com relação a Nietzsche, quero destacar aqui um aspecto especifico de investigação com a seguinte questão: até que ponto, na interpretação heideggeriana sobre o eterno retorno de Nietzsche, se abre um espaço para pensar sobre a questão do tempo? É claro que para ele o problema do tempo surge antes desse "acerto de contas" com Nietzsche, mas também não se pode negar que essa problemática se aprofunda ainda mais com a leitura que ele faz da filosofia nietzschiana.

Para compreender melhor esta questão é necessário entender em linhas gerais essa interpretação filosófica. Para Heidegger, a filosofia de Nietzsche representa o acabamento da metafísica (der Vollendung der Metaphysik), então ele ainda está dentro da história da metafísica, mas no seu final. Afirmar que Nietzsche é metafísico pode causar um grande estranhamento, pois desde Humano, demasiado humano ele realiza críticas abertas contra a metafísica. O eterno retorno tem um grande papel nessa posição antimetafísica de Nietzsche, pois, como desenvolverei melhor neste artigo, a

${ }^{1}$ MÜLLER-LAUTER, Heidegger und Nietzsche, 1.

Voluntas, Santa Maria, v.12, n.1, p. 01-26, jan/abril., 2021 
noção de que tudo retorna eternamente acarreta uma junção entre instante e eternidade, sendo por isso um elemento fundamental para suprimir a dualidade metafísica, como bem afirma Meca: “(...) o pensamento do eterno retorno é a antítese total da concepção dualista do mundo sobre a qual os ideais e os valores do niilismo se basearam, na medida em que acaba com a divisão entre mundo verdadeiro e mundo aparente" ${ }^{\prime \prime}$. Ora, essa posição contrária à metafísica por parte de Nietzsche não é o suficiente para Heidegger, pois ele não compreende por metafísica a divisão de dois mundos, o "mundo aparente" e o "mundo verdadeiro", como pensou Nietzsche e toda a tradição, mas sim como uma determinação ontológica do ser do ente, pensando sempre o ser através do ente, e não do ser. A história da metafísica tratou o ser como fundamento do ente, deixando de lado o próprio ser, ou melhor, esquecendo o ser. $\mathrm{O}$ filósofo da floresta negra considera praticamente toda a história da filosofia como dentro da metafisica: desde os pré-socráticos até Nietzsche. Como ele afirma na introdução de 1949 de O que é metafísica?: "velada permanece para a metafísica a verdade do ser ao longo de sua histórica, de Anaximandro a Nietzsche" ${ }^{\prime \prime}$. A metafísica, por considerar o ente e não a verdade do ser, é ôntica, e não ontológica. Heidegger busca formar uma autêntica ontologia por meio da sua própria filosofia desde a analítica do ser-aí (Dasein) até depois da "virada" (Die Kehre), mas que ao mesmo tempo reinterpreta e destrói a história da metafísica na medida em que o ser está ocultado nela e, por meio disso, abre um novo horizonte para pensar o ser.

É preciso destacar que, para Heidegger, tomar o ser como ente não é um erro ou engano dos metafísicos, mas é acontecimento. Metafísica e ontologia não são meramente disciplinas filosóficas que fundamentam todas as outras disciplinas (ética, epistemologia, etc), mas elas representam uma atitude de um questionamento diante do mundo dado, logo é um acontecimento do ser-aí humano, que pergunta pelo ser do ente em seu todo; trata-se do modo como o ser-aí compreende o mundo, a totalidade dos entes que vêm ao seu encontro e se constrói nesse mundo. É nesse sentido que

\footnotetext{
2 MECA, Nietzsche ou a eternidade do tempo, 193.

3 HEIDEGGER, O que é metafísica?, 79-80.
} 
Heidegger compreende Nietzsche numa perspectiva ontológica e inserido dentro da história da metafísica ou, mais do que isso, como o pensador do acabamento da metafísica.

Heidegger indica a metafísica em Nietzsche por meio de uma interpretação ôntica das principais concepções da filosofia do último Nietzsche: vontade poder, eterno retorno, niilismo, além-do-homem e justiça (em Metafísica de Nietzsche) ou transvaloração de todos os valores (em O niilismo europeu). Na preleção chamada Metafísica de Nietzsche, Heidegger sintetiza essa interpretação do seguinte modo:

\begin{abstract}
"A vontade de poder" mostra-se como a expressão para o ser do ente enquanto tal, para a essentia do ente. "Niilismo" é o nome para a história da verdade do ente assim determinado. "Eterno retorno do mesmo" designa o modo como o ente na totalidade é, a existentia do ente. "O além-do-homem" aponta para aquela humanidade que é requisitada por essa totalidade. "Justiça" é a essência da verdade do ente enquanto vontade de poder ${ }^{4}$.
\end{abstract}

Essas expressões fundamentais da filosofia nietzschiana estão conectadas, por isso é importante este destaque sobre a caracterização heideggeriana de cada uma delas. Estes vínculos serão mais bem aprofundados tendo como fio condutor o problema do eterno retorno, já colocado. A concepção de eterno retorno é essencial na interpretação de Heidegger sobre Nietzsche, pois ela diz sobre o modo da existência do ser do ente, tratando-se, então, do modo como o ente se encontra na totalidade ou, em linguagem escolástica, da quodidade.

Dado essas explicações iniciais, é possível investigar o impacto do eterno retorno no pensamento de Heidegger, principalmente em relação ao tempo. É preciso frisar, como pensa Müller-Lauter ${ }^{5}$, que as mudanças no pensamento heideggeriano em cada ano e a "virada" (Die Kehre) ocorrem nas preleções sobre Nietzsche entre 1936 e 1946 publicada em dois volumes. Nesse sentido, a interpretação em questão começa num período um pouco posterior à publicação de Ser e tempo (1927), passa pela "virada" e tem novas formas na década de 1950. Assim, analisarei primeiro a noção de tempo no eterno retorno nas preleções de Nietzsche / e depois passarei à interpretação feita na

${ }^{4}$ HEIDEGGER, Nietzsche II, 197.

${ }^{5}$ MÜLLER-LAUTER, Heidegger und Nietzsche, 28-29.

Voluntas, Santa Maria, v.12, n.1, p. 01-26, jan/abril., 2021 
década de 1950 com Quem é o Zaratustra de Nietzsche? e a preleção O que significa pensar?.

\section{$* * *$}

A referência ao tempo está constantemente nos textos de Nietzsche que abordam o eterno retorno, tanto nos fragmentos póstumos como nas obras publicadas, de tal forma que não é exagero afirmar que sua concepção de tempo é pensada pelo eterno retorno. Heidegger sabe muito bem disso e considera na preleção Vontade de poder como arte que "pensar o ser, a vontade de poder, como eterno retorno, pensar o pensamento mais pesado da filosofia significa pensar o ser como tempo. Nietzsche pensou esse pensamento. No entanto, ele não chegou a pensá-lo como pergunta sobre ser e tempo"6. Por outro lado, isso não significa "que a obra de Nietzsche está ligada a uma obra com o título Ser e tempo, e que ela é interpretada e medida segundo o que se encontra nesse livro"7, então, embora o problema sobre ser e tempo esteja no filósofo do eterno retorno, isso não legitima medi-lo por meio da obra Ser e tempo, até porque Heidegger já considera essa obra como limitada, quando diz: "até que ponto ele [Ser e tempo] está à altura da questão por ele levantada e até que ponto ele não está" ${ }^{\prime}$. O essencial é a questão que Ser e tempo coloca e não propriamente o livro em si, pois "o livro só nos conduz até o limiar da questão: ele ainda não é capaz de nos levar para o interior da questão mesma" ${ }^{9}$. Nota-se, com isso, já certa insatisfação de Heidegger com seu projeto de analítica do ser-aí.

Outro aspecto relevante dessa passagem citada é a junção que Heidegger realiza entre eterno retorno e vontade de poder. Essa posição está baseada principalmente no fragmento póstumo 7[54] de 1886 e 1887 que não só expressa a junção entre eterno retorno e vontade de poder, mas compreende os dois por meio da ligação entre devir e ser. O fragmento diz: "Imprimir ao devir o caráter do ser: essa é a suprema vontade de

\footnotetext{
${ }^{6}$ HEIDEGGER, Nietzsche I, 20.

7 HEIDEGGER, Nietzsche I, 21.

8 HEIDEGGER, Nietzsche I, 21.

${ }^{9}$ HEIDEGGER, Nietzsche I, 21.
} 
poder. (...) Que tudo retorna é a extrema aproximação de um mundo do devir ao mundo do ser." ${ }^{\prime 10}$

Heidegger cita constantemente esse fragmento póstumo quando interpreta Nietzsche, pois nele está escrito de maneira mais nítida uma formulação ontológica sobre vontade de poder e eterno retorno. Na preleção Vontade de poder como arte, essa passagem é chave para compreender a filosofia nietzschiana como inversão do platonismo, pois, já na juventude (1870), Nietzsche afirma no fragmento póstumo 7 [156]: "Minha filosofia é platonismo invertido." 11 Para Heidegger, a inversão do platonismo só fica mais clara nos últimos escritos de Nietzsche na medida em que se busca superar o niilismo, ou seja, o processo de desvalorização dos valores supremos e a falta de sentido, pois, como diz Heidegger, "a inversão do platonismo significa, inicialmente: abalo do primado do suprassensível como ideal."12. Se o suprassensível é abalado, então o sensível não é mais interpretado pelos valores supremos. Com a superação do niilismo, não apenas se instaura novos valores, mas um novo modo de valorizar. Inverter o platonismo não significa simplesmente inverter o sensível e o suprassensível, pois, como diz Heidegger, com isso "são mantidos como que os lugares vazios do acima e do embaixo, e eles não são senão ocupados de maneira diversa. Mas, na medida em que esse acima e esse embaixo determinam a estrutura do edifício do platonismo, ele continua subsistindo em sua essência"13. Com a supressão do mundo verdadeiro não subsiste o mundo aparente, "pois o mundo aparente só pode ser o que ele é como a parte contrária do mundo verdadeiro"14, logo se o mundo aparente se forma pela perspectiva do mundo verdadeiro, então ele também deve desaparecer, e é isso que Nietzsche faz no final do pequeno capítulo de Crepúsculo dos ídolos, chamado Como o "mundo verdadeiro" se tornou finalmente fábula: "Abolimos o mundo verdadeiro: que mundo restou? O aparente talvez?... Não! Com o mundo verdadeiro abolimos

\footnotetext{
10 NIETZSCHE,. Sämtlich Werke, v. 12, 312.

11 NIETZSCHE,. Sämtlich Werke, v. 7, 199.

12 HEIDEGGER. Nietzsche I, 145.

13 HEIDEGGER. Nietzsche I, 179.

14 HEIDEGGER. Nietzsche I, 179.
}

Voluntas, Santa Maria, v.12, n.1, p. 01-26, jan/abril., 2021 
também o mundo aparente!"15. Com isso, Nietzsche inverte o platonismo de modo que não apenas mudam de lugar as posições entre aparência e verdade, mas, como diz Heidegger, dá um giro para fora de si e desemboca na transformação do homem ${ }^{16}$. Para o filósofo da floresta negra, a supressão do mundo suprassensível e sensível na inversão do platonismo quer reinterpretar o sensível a partir de uma nova hierarquização do sensível e do não-sensível que "não quer simplesmente inverter as coisas no interior do antigo esquema ordenador, só reverenciando agora o sensível e depreciando o não-sensível (...). Uma nova ordem hierárquica e uma nova avaliação significa: transformar o esquema ordenador"17; por isso essa "inversão precisa se tornar um giro para fora do platonismo"18.

Esse "giro para fora do platonismo" muda completamente a relação entre ser e devir da metafísica clássica (ou do platonismo). Nietzsche pensou os dois em junção com os conceitos de vontade de poder e eterno retorno, tal como já notado no fragmento póstumo 7[54]. Como afirma Heidegger: “Assim, Nietzsche procura pensar conjuntamente na vontade de poder a unidade originária da antiga contradição entre ser e devir. Ser como a constância deve deixar o devir ser um devir. A origem da ideia do 'eterno retorno' é com isso, indicada." ${ }^{19}$.

Heidegger pensa vontade de poder em relação essencial com o eterno retorno do mesmo, pois projeta o ente na entidade tendo em vista na constância e presença. Assim, a vontade de poder é compreendida como a transformação do devir em algo constante, e, por isso, entende vontade de poder no termo metafísico de quididade, ou seja, diz o que o ente é. Então, para Heidegger, se por um lado vontade de poder representa o ser do ente como fim da metafísica na medida em que decompõe a oposição entre ser e devir, por outro o devir torna o constante como presença incondicionada, transformando o caos em uma constância. O problema do tempo no

\footnotetext{
15 NIETZSCHE, Crepúsculo dos ídolos, 29.

16 HEIDEGGER, Nietzsche I, 185.

17 HEIDEGGER. Nietzsche I, 186.

18 HEIDEGGER. Nietzsche I, 186.

19 HEIDEGGER. Nietzsche I, 193.
}

Voluntas, Santa Maria, v.12, n.1, p. 01-26, jan/abril., 2021 
eterno retorno tem como pressuposto essa relação essencial dele com a vontade de poder, pois por meio do tempo é possível pensar a junção entre ser e devir.

Na preleção $O$ eterno retorno do mesmo, Heidegger propõe examinar o eterno retorno como fundamento da filosofia nietzschiana, pois ele trata do ente na totalidade ${ }^{20}$ que confronta com o pensamento cristão e platônico. Dado isso, Heidegger analisa o eterno retorno tanto nas obras publicadas, como nos fragmentos póstumos. Analisarei aqui mais as obras publicadas, pois nelas aparece mais a questão do tempo, principalmente a seção Da visão e do enigma de Assim falou Zaratustra.

O eterno retorno aparece pela primeira vez nas obras publicadas no aforismo 341 de A gaia ciência, título esse que para Heidegger ${ }^{21}$ não quer dizer uma ciência especializada e moderna e "gaia" (em alemão é fröhlich, literalmente alegre) não é divertimento superficial, mas anuncia o saber do eterno retorno, pois "Gaia ciência: isso não é, para Nietzsche, outra coisa senão o nome para a 'filosofia', para aquela filosofia que ensina em sua doutrina fundamental o eterno retorno do mesmo"22. O título do aforismo é $O$ mais pesado dos pesos. Esse peso, para Heidegger indica estar no meio do ente na totalidade ${ }^{23}$. O aforismo começa convidando o leitor a realizar uma hipótese fabulosa que se inicia nos seguintes termos: "E se um dia ou uma noite um demônio se esgueirasse em tua mais solitária solidão e te dissesse."24 O pensamento não surge a partir de um homem, mas sim de um demônio. Tampouco surge para um homem qualquer, como um negociante esquecido de si mesmo, mas sim de alguém na "mais solitária solidão". Aqui solidão não é puramente um isolar-se, se afastar de toda sociedade, mas como afirma Heidegger, trata-se de "quando se encontra nas relações essenciais de sua existência histórica em meio ao ente na totalidade"25.

E o que diz o demônio? Trata-se do eterno retorno, ou melhor, da suposição do eterno retorno tanto da sua vida, como de cada pequeno elemento e grande elemento:

\footnotetext{
${ }^{20}$ HEIDEGGER. Nietzsche I, 198.

${ }^{21}$ HEIDEGGER. Nietzsche I, 209-210.

22 HEIDEGGER. Nietzsche I, 210.

${ }^{23}$ HEIDEGGER. Nietzsche I, 211.

${ }^{24}$ NIETZSCHE, Gaia ciência, 193.

25 HEIDEGGER, Nietzsche I, 213.
} 
"Esta vida, assim como tu a vives e como a viveste, terá de vivê-la ainda uma vez e ainda inúmeras vezes; e não haverá nela nada de novo, cada dor e cada prazer e cada pensamento e suspiro e tudo o que há de indizivelmente pequeno e de grande em tua vida há de te retornar, e tudo na mesma ordem e sequência - e do mesmo modo esta aranha e este luar entre as árvores, e do mesmo modo este instante e eu próprio. A eterna ampulheta da existência será sempre virada outra vez - e tu com ela, poeirinha da poeira!"26.

Assim, o demônio afirma a eterna repetição da vida, que será vivida repetidamente e exatamente da mesma forma, cada suspiro, pensamento, e tudo que é grande e pequeno retornarão inúmeras vezes. No final, a fala do demônio mostra que a repetição da vida individual é uma consequência da repetição da existência: "A eterna ampulheta da existência será sempre virada outra vez - e tu com ela, poeirinha da poeira!". Portanto, o tempo em devir é uma ampulheta que gira eternamente, o tempo é circular e não linear.

Nietzsche coloca duas possibilidades de reação do indivíduo diante do eterno retorno: uma é o "ranger os dentes e amaldiçoarias o demônio que falasse assim"27; trata-se de uma não aceitação da vida como ela é, ver a eterna repetição como um constante sofrimento que busca ser negado. A outra reação é ter um instante descomunal e dizer "Tu és um deus, e nunca ouvi nada mais divino!" 28 Trata-se de reconhecer a eterna repetição da vida como algo divino, e não apenas suportar essa vida, mas amar e a querer eternamente, mesmo com as suas dores imanentes à vida. Diante da eterna repetição, Nietzsche coloca a seguinte questão: "quero isto ainda uma vez e ainda inúmeras vezes?", e essa pergunta "pesaria como o mais pesado dos pesos sobre teu agir!"29. Portanto, a hipótese da eterna repetição da existência é o peso mais pesado sobre nossa ação, pois todo agir tem o peso da eternidade.

Heidegger se pergunta sobre esse aforismo: "o que acontece quando esse pensamento é realmente pensado?" ${ }^{\prime 30}$ A resposta está no aforismo seguinte de $A$ gaia ciência chamado Incipit tragoedia (A tragédia começa). Para Heidegger trata-se da

\footnotetext{
${ }^{26}$ NIETZSCHE, Gaia ciência, 193.

27 NIETZSCHE, Gaia ciência, 193.

${ }^{28}$ NIETZSCHE, Gaia ciência, 193.

${ }^{29}$ NIETZSCHE, Gaia ciência, 193.

30 HEIDEGGER, Nietzsche I, 215.
}

Voluntas, Santa Maria, v.12, n.1, p. 01-26, jan/abril., 2021 
tragédia do ente enquanto ta| ${ }^{31}$ e isso retoma ao livro 0 nascimento da tragédia (1872), pois o trágico não é káӨapoıs de Aristóteles que liga pavor e compaixão, nem nada moral, mas estético: “a arte é 'a' atividade metafísica da 'vida'; ela determina como o ente na totalidade é, na medida em que ele é: a arte maximamente elevada é a arte trágica; ou seja, o trágico constitui a essência metafísica do ente" ${ }^{\prime 32}$. 0 trágico não é meramente uma manifestação artística, mas sim metafísico e ontológico. Porém, aqui, o Incipit tragoedia se transforma em Incipit Zaratustra, pois nesse aforismo está escrito algo semelhante ao prólogo de Assim falou Zaratustra que narra os primeiros passos de Zaratustra no seu declínio. Eterno retorno e Zaratustra se coexistem, pois o "pensamento do eterno retorno é a essência de Zaratustra"33. Portanto, a obra Assim falou Zaratustra é a segunda comunicação da doutrina do eterno retorno ${ }^{34}$ : Zaratustra é um pensador ou herói trágico cujo fundamento é o eterno retorno. Para Heidegger, Nietzsche projeta na figura de Zaratustra o espaço da "mais solitária solidão" do aforismo de $A$ gaia ciência, mas com a possibilidade de estar bem com a vida ${ }^{35}$.

O capítulo Da visão e do enigma da Parte III de Assim falou Zaratustra trata "do enigma no qual o ente na totalidade se oculta com 'a visão do homem mais solitário' $(\text {.... })^{\prime 36}$. O discurso Da visão e enigma narra o início da viagem de navio em que Zaratustra fica frio, surdo e mudo de tristeza por três dias, até que por fim ele narra aos marinheiros do navio o enigma que viu. E o que diz o enigma? Trata-se de uma caminhada de Zaratustra no qual buscava o alto, mas um anão Ihe pingava chumbo aos ouvidos e puxava-o para baixo, para o abismo, enquanto ele subia. Então, com uma coragem - que mata o desânimo, a vertigem diante do abismo, a compaixão e até mesmo a própria morte ao dizer "Isso era vida? Muito bem! Mais uma vez!" ${ }^{37}$. Com essa

\footnotetext{
31 HEIDEGGER, Nietzsche I, 215.

32 HEIDEGGER, Nietzsche I, 216.

33 HEIDEGGER, Nietzsche I, 218.

${ }^{34}$ HEIDEGGER, Nietzsche I, 219.

35 HEIDEGGER, Nietzsche I, 221.

${ }^{36}$ HEIDEGGER, Nietzsche I, 223.

37 NIETZSCHE, Assim falou Zaratustra, 150.
} 
coragem Zaratustra diz "Alto lá, anão! Eu, ou tu! Mas eu sou mais forte de nós dois-: tu não conheces meu pensamento abismal!"38

Assim, o anão pula do ombro de Zaratustra e ambos se veem diante de um portal. Esse portal é descrito por Zaratustra como duas ruas, um lado está indo para trás com uma eternidade, e outro lado está indo para frente com outra eternidade. E essas duas ruas "não se contradizem, esses caminhos; eles se chocam frontalmente:- é aqui, neste portal, que eles se encontram. O nome do portal está em cima 'Instante'"39 O portal faz a imagem do tempo que corre para trás e para frente eternamente. A respeito disso, Heidegger afirma:

O portal "instante" com as suas ruas infinitamente contrapostas perfaz a imagem do tempo que corre para a frente e para trás até a eternidade. O tempo mesmo é visto a partir do "instante", a partir do "agora", do qual um caminho conduz adiante para o ainda-não-agora, para o cerne do futuro, e do qual o outro caminho reconduz ao não-mais-agora, ao passado. Na medida em que a visualização do portal deve trazer ao anão encarapitado ao lado de Zaratustra a visão do pensamento mais abismal, mas em que nessa visão devem ser evidentemente concretizados por meio de uma imagem sensível do tempo e eternidade, então o todo diz: o pensamento do eterno retorno do mesmo é articulado agora com o âmbito do tempo e da eternidade. Mas essa visão, o portal visto, é a visualização do enigma, não a sua dissolução ${ }^{40}$.

O enigma é o portal do “instante" que corre para trás e para frente, sendo, portanto, o enigma do tempo que o eterno retorno coloca. O enigma se concretiza nas seguintes palavras de Zaratustra: “Mas, se alguém seguisse por um deles - sempre mais adiante e mais longe: acreditas, anão, que esses caminhos se contradizem eternamente?" 41 E o anão responde: “'Tudo que é reto mente', murmurou desdenhosamente o anão. 'Toda verdade é curva, o próprio tempo é um círculo'"42. Assim, a afirmação da circularidade do tempo é a primeira resposta dada ao enigma. O que nos parece ser duas ruas que seguem justamente uma para fora da outra é, na verdade, apenas o trecho inicialmente visível de um grande círculo. Sobre isso,

\footnotetext{
38 NIETZSCHE, Assim falou Zaratustra, 150.

${ }^{39} \mathrm{NIETZSCHE}$, Assim falou Zaratustra, 150.

40 HEIDEGGER, Nietzsche I, 227.

${ }^{41}$ NIETZSCHE, Assim falou Zaratustra, 150.

${ }^{42}$ NIETZSCHE, Assim falou Zaratustra, 150.
} 
Heidegger observa: "A autocirculação do tempo, e, com isso, o retornar-sempre do mesmo de todo ente no tempo, é o modo como o ente na totalidade é" ${ }^{43}$. Essa é a solução do enigma do anão. Entretanto, mesmo essa solução afirmando o eterno retorno e não sendo falso, Zaratustra não diz que o anão solucionou o enigma, pelo contrário, ele se irrita e considera superficial e leviana a resposta do anão, pois Zaratustra enfatiza a questão do instante:

Olha (...) esse instante! Desde esse portal, uma longa rua eterna conduz para trás: atrás de nós há uma eternidade. Tudo aquilo que pode andar, de todas as coisas, não tem de haver percorrido esta rua alguma vez? Tudo aquilo que pode ocorrer, de todas as coisas, não tem de haver ocorrido, sido feito, transcorrido alguma vez? E se, tudo já esteve aí, que achas, anão, desse instante? Também esse portal não deve já - ter estado aí? E todas as coisas não se acham tão firmemente atadas que esse instante carrega consigo todas as coisas por vir? Portanto--, também a si mesmo? Pois o que pode andar, de todas as coisas, também nessa longa rua para lá - tem de andar ainda alguma vez!- E essa lenta aranha que se arrasta à luz da lua, e essa luz mesma, e tu e eu junto ao portal sussurrando um para outro, sussurrando sobre coisas eternas - não temos de haver existido todos nós? - e de retornar e andar nessa outra rua, lá, diante de nós, nessa longa e horripilante rua - não temos de retornar eternamente?-44.

Portanto apesar de Zaratustra colocar o anão para o alto, onde ele poderia ver o enigma, ele continua na visão baixa e limitada. E também, apesar de ele dizer a verdade, isso ainda não é suficiente para desvendar toda profundidade do enigma, pois ele deve ser pensado a partir do "instante". Na sua preleção, Heidegger expõe os pressupostos fundamentais que não são visíveis nessa passagem, a saber: "1- A infinitude do tempo segundo a direção do futuro e do passado. 2. A realidade do tempo que não é nenhuma forma 'subjetiva' da intuição. 3. A finitude das coisas e de seus decursos coisais" ${ }^{45}$. Tudo que será deve ter sido como ente nesses pressupostos, "pois em um tempo infinito o curso de um mundo finito já teria necessariamente consumado"46. Porém, com essa questão de Zaratustra, o anão não diz mais nada, pois já se colocou um aspecto

\footnotetext{
${ }^{43}$ HEIDEGGER, Nietzsche I, 228.

${ }^{44}$ NIETZSCHE, Assim falou Zaratustra, 150-151.

${ }^{45}$ HEIDEGGER, Nietzsche I, 229.

${ }^{46}$ HEIDEGGER, Nietzsche I, 229.
}

Voluntas, Santa Maria, v.12, n.1, p. 01-26, jan/abril., 2021 
fundamental: o instante. Isso significa que com a questão do "instante" se está "no tempo e em sua temporalidade" ${ }^{47}$.

A metafísica e o cristianismo têm uma concepção de tempo linear numa sucessão entre passado, presente e futuro e, separada dele, há uma eternidade atemporal, o ser eterno. Com isso, o devir é desvalorizado como uma efemeridade sensível e, por outro lado, a eternidade contém a essência do mundo. Com o eterno retorno o tempo é circular, ao invés de ser linear, e nele o instante se repete eternamente. Ao conceber o instante como sendo, ao mesmo tempo, perecível e eterno, Nietzsche se afasta da dicotomia metafísica que tem uma oposição entre as coisas sensíveis-perecíveis e a eternidade, ser e devir, verdade e aparência.

Porém, é preciso retomar ao enigma do "instante", pois nele se concentra a questão do tempo. $\mathrm{O}$ anão viu apenas duas ruas em direção opostas levando para a eternidade, mas ele não vê que "as duas ruas 'dão com a cabeça uma na outra' no portal"48. Isso faz toda diferença, pois no instante futuro e passado se chocam, e isso ocorre para aquele que não é só o espectador, tal como foi o anão, mas sim "para aquele que é antes ele mesmo o instante que age e se projeta para o futuro e que aí não deixa cair o passado, mas muito mais o acolhe a afirma"49. Quem está no instante se encontra no conflito entre passado e futuro, mas o anão ficou de fora. Quem está no instante, está também na essência do ser e tempo. Disso, Heidegger chega a uma conclusão de suma importância sobre o eterno retorno e o tempo:

Com tudo isso, o que é dito sobre o modo correto de pensar o pensamento do eterno retorno? Diz-se algo essencial: o que diz respeito ao futuro é justamente uma questão de decisão, o anel não se fecha em um lugar qualquer no infinito, mas tem seu fechamento inquebrado no instante como o meio de contenda; o que retorna - quando retorna - é decidido pelo instante e pela força de dominação das coisas contraditórias que nele se chocam. Isso é o que há de mais pesado e o que há de próprio à doutrina do eterno retorno, que a eternidade esteja no instante, que o instante não seja o agora fugaz, que não seja um momento apenas escorregando e passando ao largo de um certo espectador, mas sim a colisão de futuro e passado. Nessa colisão, o instante vem até si mesmo. Ele determina como tudo retorna ${ }^{50}$.

\footnotetext{
${ }^{47}$ HEIDEGGER, Nietzsche I, 229.

48 HEIDEGGER, Nietzsche I, 241.

${ }^{49}$ HEIDEGGER, Nietzsche I, 241.

50 HEIDEGGER, Nietzsche I, 241.
}

Voluntas, Santa Maria, v.12, n.1, p. 01-26, jan/abril., 2021 
O instante não é apenas um fluir, mas é uma colisão da eternidade do passado e do futuro. Em suma, o instante é eternidade. Ora, se a eternidade foi colocada pelo pensamento metafísico vigente como "mundo verdadeiro e suprassensível", agora ela não se encontra mais aí, até mesmo pelo fato de não existir esse "mundo verdadeiro e suprassensível". Também não se pode dizer que com Nietzsche a eternidade está no "mundo aparente e sensível", pois, como já destaquei, com a inversão do platonismo o "mundo aparente" também foi suprimido. Afirmar que o instante é eternidade significa o fim da metafísica, mas para Heidegger esse fim está ainda no interior dela.

Entretanto, Heidegger observa ainda um aspecto muito importante na visão do instante como colisão de passado e futuro mais adiante, a saber, nessa colisão está presente o homem. Se há um pensamento do ente na totalidade pelo eterno retorno, então ele precisa estar ligado ao homem. E isso ocorre justamente por o eterno retorno ser pensado pelo instante, uma vez que com isso o homem é o instante enquanto eternidade na colisão entre passado e futuro:

Determinamos como "instante" aquele tempo no qual o futuro e o passado dão com a cabeça um no outro, o tempo no qual o passado e o futuro são decisivamente realizados e consumados pelo homem, na medida em que o homem se acha na posição dessa colisão, sim, na medida em que ele não é outra coisa senão essa colisão. A temporalidade do tempo da eternidade que precisa ser pensada no eterno retorno do mesmo é a temporalidade na qual antes de tudo e, até onde sabemos, apenas o homem se encontra, uma vez que ele, decididamente aberto para o futuro, guardando o passado essencial, configura e suporta o que está presente ${ }^{51}$.

Essa interpretação do eterno retorno é de suma importância para a filosofia heideggeriana, pois ele não só recusa a oposição entre tempo e eternidade, mas também considera essencial pensar a temporalidade por meio daquilo que somos. Heidegger escreve na introdução de Ser e tempo: "A temporalidade (Zeitlichkeit) será mostrada como o sentido do ser desse ente que denominamos Dasein" ${ }^{\prime 25}$. É claro que a analítica do ser-aí não pensa ser e tempo como eterno retorno, tal como já destaquei, mas pelo eterno retorno é possível realizar um diálogo com o problema do ser

\footnotetext{
51 HEIDEGGER, Nietzsche I, 276.

52 HEIDEGGER, Ser e tempo, 75.
}

Voluntas, Santa Maria, v.12, n.1, p. 01-26, jan/abril., 2021 
enquanto tempo. Como já mostrei, nesse período em que Heidegger leciona sobre Nietzsche está ocorrendo a "virada" (Die Kehre) em que o ser já não é temporal porque constitui unidade horizontal da temporalidade do ser-aí, mas o próprio ser destina ao homem sua essência como ser-aí. Até que ponto o eterno retorno de Nietzsche tem um papel nisso? Talvez ainda não haja aqui a base suficiente para responder essa pergunta, principalmente nas preleções de Nietzsche I, mas dois aspectos da noção de tempo em Nietzsche tratado por Heidegger merecem destaque. Em primeiro lugar, Heidegger considera a noção de Nietzsche sobre o tempo de maneira insuficiente e raramente vai além da concepção tradicional do tempo ${ }^{53}$, por isso ele ainda é metafísico. Em segundo lugar, se Nietzsche pensa a partir do instante, o eterno retorno é uma superação do niilismo ${ }^{54}$. Isso fica nítido no capítulo $A$ visão e o enigma de Assim falou Zaratustra, em que aparece a serpente negra na boca do pastor e ele precisa morder e cuspir, se transformando em um iluminado que ria como jamais se riu na Terra. Como o próprio Heidegger reconhece, essa serpente negra ilustra o niilismo ${ }^{55}$, logo o eterno retorno de Nietzsche trás a possibilidade de superação do niilismo, o que, como veremos, pode representar um novo pensamento porvir.

\section{*ᄎ*}

Na década de 1950, Heidegger interpreta novamente Nietzsche, mas é preciso apontar que ele já não era o mesmo do das preleções de Nietzsche l.: a virada já tinha sido publicamente manifestada na Carta sobre o humanismo em 1947 e ele não tinha mais a perspectiva de fundar uma ontologia pela analítica do ser-aí, ao invés disso ele nota a possibilidade de pensar ser e tempo por meio do acontecimento apropriador (Ereignis). Nesse sentido, concordo com Müller-Lauter ${ }^{56}$ que os escritos sobre Nietzsche na década de 1950 têm acento diferente da interpretação anterior. Na preleção O que significa pensar? e no ensaio Quem é o Zaratustra de Nietzsche?, não só Assim falou

\footnotetext{
53 HEIDEGGER, Nietzsche I, 269.

${ }^{54}$ HEIDEGGER, Nietzsche I, 347.

55 HEIDEGGER, Nietzsche I, 344.

${ }^{56}$ MÜLLER-LAUTER, Heidegger und Nietzsche, 75-76.
} 
Zaratustra toma uma posição mais central, como também Nietzsche abre um novo caminho para o pensamento.

Em Quem é o Zaratustra de Nietzsche? Heidegger utiliza passagens de Assim falou Zaratustra para caracterizar Zaratustra como mestre do eterno retorno e além-dohomem (Übermensch) que se refere ao que está para além do que o homem se construiu a partir de si mesmo e consigo mesmo. "O homem é algo que deve ser superado"57 Por isso a preferência da tradução do termo por além-do-homem, pois é algo que se estende para além da humanidade, isso significa, está para além das construções morais pelo qual o homem forma a si mesmo. Ele é, portanto, aquele que está preparado para viver numa superação da moral, pois até agora o homem nada mais foi do que uma auto-construção da moral.

Heidegger, ao se questionar sobre a necessidade do além-do-homem, considera que "Nietzsche reconhece o instante histórico em que o homem se prepara para entrar na total dominação da Terra"58. Para o homem assumir a dominação da Terra, seria necessário o homem ir para além de si mesmo para poder corresponder a essa missão. Essas são questões que tratam sobre o amanhã, sobre o futuro do homem e da Terra. O além-do-homem ultrapassa o homem ainda hoje vigente e, nessa ultrapassagem, Heidegger nota o grande anseio de Zaratustra, destacando uma passagem do discurso Do grande anseio: “Ó minha alma, eu te ensinei a dizer 'hoje' assim como 'um dia' e 'outrora' e a dançar tua ciranda sobre todo aqui, ali e acolá." 59 Heidegger destaca as três palavras que se referem ao temporal ("hoje", "outrora" e "algum dia") e nota que elas convergem para um mesmo num único presente que é a eternidade: "Também Nietzsche pensa as três fases do tempo a partir da eternidade como agora permanente. A permanência não consiste para ele num estar, mas num retorno do mesmo. $O$ eterno retorno é a inesgotável plenitude da vida na sua alegria e na sua dor"60 Essa indicação do eterno retorno já difere do mote de constância do devir nas preleções Nietzsche l e

\footnotetext{
57 NIETZSCHE, Assim falou Zaratustra, 13

58 HEIDEGGER, Quem é o Zaratustra de Nietzsche?, 91.

${ }_{59}$ NIETZSCHE, Assim falou Zaratustra, 212.

60 HEIDEGGER, Quem é o Zaratustra de Nietzsche?, 94-95. Ligeira modificação na tradução.
} 
II, e passa a considerar como afirmação da vida na alegria e na dor, o que muda de uma perceptiva técnica de Nietzsche para uma poética, como pretendo demonstrar. $\mathrm{O}$ grande anseio é, portanto, um anseio de superabundância, que cria o consolo, a confiabilidade.

Assim, Heidegger questiona: qual é essa esperança? Qual a ponte para a ultrapassagem do homem vigente? Heidegger aponta a resposta para essas questões por meio da concepção de redenção da vingança, presente em Das tarântulas em Assim falou Zaratustra: "Pois que o homem seja redimido da vingança: isso é, para mim, a ponte para a mais alta esperança e um arco-íris após longos temporais." meta do pensamento de Nietzsche é a redenção do espírito de vingança". ${ }^{62}$ Então, o pensamento de Nietzsche quer servir o espírito de liberdade em relação à sede de vingança, do querer punir e que "em relação à vingança, o espaço desta liberdade está equidistante tanto do pacifismo quanto da política de força ou neutralidade calculada"63. Nota-se que Heidegger se afasta de uma interpretação de Nietzsche como administração técnica calculadora da Terra, no lugar disso se tem a libertação em relação ao espírito de vingança que está relacionado com o eterno retorno e a concepção de tempo e devir presente nele.

Assim, Heidegger questiona: "mas, que entende Nietzsche aqui por vingança? Segundo ele, em que consiste a redenção da vingança?" ${ }^{64}$ Na preleção, O que significa pensar? Heidegger afasta a noção de vingança tratada por Nietzsche como algo psicológico ou moral, pois "a 'moral' e a 'psicologia' estão fundadas no metafísico"65, ou seja, na medida em que vingança está relacionada com o ser do ente. Para isso, Heidegger recorre à outra passagem de Assim falou Zaratustra chamada Da redenção que afirma: "O espírito da vingança: meus amigos, até agora foi essa a melhor reflexão dos homens; e onde havia sofrimento deveria sempre haver castigo." $66 \mathrm{O}$ filósofo da

\footnotetext{
61 NIETZSCHE, Assim falou Zaratustra, 95.

62 HEIDEGGER, Qué significa pensar?, 57.

63 NIETZSCHE, Assim falou Zaratustra, 96.

64 HEIDEGGER, Quem é o Zaratustra de Nietzsche?, 96.

65 HEIDEGGER, Qué significa pensar?, 58.

${ }_{66}$ NIETZSCHE, Assim falou Zaratustra, 133-134.
} 
floresta negra entende que essa frase representa a reflexão do homem até hoje em que pensa o ente, então está ligada com a relação do homem com o que é, o homem pensa o ser a partir do ente, ou melhor, indo para além dele em direção ao ser, por isso é uma metafísica: "em suma: ele representa o ente no tocante ao seu ser"67. E por isso, quando Nietzsche pensa o ente como ser, ele já pensa metafisicamente.

Analisando a palavra vingança (Rache) etimologicamente, Heidegger relaciona com impelir, impulsionar, perseguir, buscar, pois a vingança se vinga de algo que tomou pelo sentimento de ter sido vencido e lesado, então "vingança é a perseguição que resiste, opõe-se e subestima"68. Para compreender a vingança como ser do ente do pensar vigente até hoje, Heidegger recorre ao conceito de vontade que Schelling, em Investigações filosóficas sobre a essência da liberdade humana e das questões conexas, considera que o ser é vontade, ou seja, todos os predicados essenciais do ser se concentram no conceito de vontade, tal como ausência de fundamento, eternidade, independência em relação ao tempo, autoafirmação. A vontade não é uma faculdade humana, mas nomeia o ser em sua totalidade e, para Heidegger, essa concepção ontológica de vontade está em muitos filósofos modernos como Leibniz, Kant, Fichte, Hegel, Schopenhauer e, por fim, no próprio Nietzsche. Para a metafísica moderna, o ser que é se manifesta como vontade, mas o homem é homem por se relacionar com o ente, se relacionando com o ser do ente enquanto vontade. E com isso, para saber o que é vingança (tendo em vista que ela determina todo pensamento ocidental), Heidegger cita novamente Da redenção: “Isto, e apenas isto, é a própria vingança: a aversão da vontade pelo tempo e seu 'foi"'69.

Assim, se destaca o aspecto da vingança com a sua aversão (Widerwille), no sentido de perseguir ao que foi muito próprio da vingança. Porém, vingança não é apenas aversão, ela é a "aversão da vontade", e, como já dito, aqui Heidegger relaciona a vontade não como faculdade humana, mas como ser em seu todo, logo "aversão da

\footnotetext{
${ }^{67}$ HEIDEGGER, Quem é o Zaratustra de Nietzsche?, 97. Ligeira modificação da tradução.

68 HEIDEGGER, Quem é o Zaratustra de Nietzsche?, 98.

${ }^{69}$ NIETZSCHE, Assim falou Zaratustra, 133.
}

Voluntas, Santa Maria, v.12, n.1, p. 01-26, jan/abril., 2021 
vontade" permanece no "interior da relação como o ser daquilo que é a perseguição que resiste e reluta, própria da vingança." ${ }^{170}$ Para Heidegger, isso se torna ainda mais claro quando se mostra contra o que é a aversão da vontade, a saber, contra o tempo e o seu "foi". Com isso, Nietzsche não se refere apenas ao tempo em geral, o seu passado, presente e futuro, mas ele enfatiza o "foi", ou seja, o seu passar, o seu caráter efêmero, como bem nota Heidegger:

Ora, o que acontece com o tempo? Acontece-Ihe que ele se vai. E ele se vai à medida que passa. O tempo que vem jamais vem para permanecer, mas para ir-se embora. Para Onde? Vai-se no passar. Quando um homem morre, costuma-se dizer que ele abençoou o temporal. O temporal equivale ao transitório, ao efêmero ${ }^{71}$.

Não se trata de enfatizar um aspecto isolado do temporal (passado) e deixar de lado os outros aspectos (presente e futuro) com o "foi", mas trata-se do tempo em sua essência própria e plena: “Com o 'e', no emprego 'o tempo e seu 'foi', Nietzsche não desvia para o mero acréscimo de um caráter particular do tempo. O e aqui significa tanto quanto: e isto quer dizer."12 Portanto, a vingança é a aversão da vontade contra o tempo, ou seja, sua transitoriedade, seu passar, sua passagem no que foi. Como afirma Nietzsche: "A vontade não pode querer para trás; não poder quebrantar o tempo e o apetite do tempo - eis a solitária aflição da vontade"73 $\mathrm{A}$ impotência da vontade diante do tempo e o "foi" é bem notado por Heidegger:

\footnotetext{
A transitoriedade é para a vontade isto contra o que ela nada mais pode, contra o que seu querer insistentemente se choca. O tempo e seu "foi" é a pedra que a vontade não pode rolar. Enquanto passar, o tempo é o adverso no qual a vontade padece. Como vontade que sofre e padece, ela se faz a dor no passar, dor esta que então quer seu próprio passar e com isso quer que tudo mereça que tudo seja digno de passar. A aversão contra o tempo subestima o transitório. O terreno, a Terra e tudo que a ela pertence é o que verdadeiramente não deveria ser e no fundo também não tem nenhum ser verdadeiro. Platão já o denomina o $\mu$ ก̀ öv, o não-ente. ${ }^{74}$.
}

\footnotetext{
70 HEIDEGGER, Quem é o Zaratustra de Nietzsche?, 100.

71 HEIDEGGER, Quem é o Zaratustra de Nietzsche?, 100.

72 HEIDEGGER, Quem é o Zaratustra de Nietzsche?, 101.

73 NIETZSCHE, Assim falou Zaratustra, 133.

${ }^{74}$ HEIDEGGER, Quem é o Zaratustra de Nietzsche?, 101. Ligeiras mudanças na tradução.
} 
Ora, a vontade como ser primordial, caracterizada pelo paradigma de Schelling, tem como característica justamente algo independente ao tempo, atemporal, eterno. Com isso, nota-se, por meio do tempo, o que significa para Heidegger o fato de Nietzsche ser o acabamento da metafísica, pois toda metafísica, desde Platão, colocou o tempo como o que não é, como o que não tem de verdadeiro, sendo oposto ao ser como vontade da filosofia moderna. Heidegger observa que "para Nietzsche, a vingança mais profunda consiste naquela reflexão que coloca os ideais supratemporais como absolutos, confrontando com os quais o temporal precisa subestimar-se como não-ente." 75 Com o filósofo de Zaratustra, tempo deixa de ser um puro passar e efêmero sensível, mas é a abertura essencial da existência. Para Heidegger, Nietzsche entende que o homem não pode assumir a dominação (não técnica) sobre a Terra, ou seja, um guardar e salvar a Terra, se subestimar o que é terreno, ou seja, o tempo e o "foi" que o espírito de vingança tem como aversão de sua vontade. É preciso, portanto, que o espírito de vingança desapareça. Somente com a redenção do espírito de vingança se tem uma esperança.

Em que consiste, portanto, a redenção da vingança? Ela não quer dizer uma negação da vontade e do ser para um nada. A redenção é em relação à aversão da vontade, aquilo que a vontade repulsa, repugna, não aceita e range os dentes contra, mas não é uma negação da vontade. Nietzsche não cai em um nada absoluto. Como afirma Heidegger: "A redenção libera a aversão de seu não e a liberta para um sim. O que afirma este sim? Precisamente isso que a aversão do espírito de vingança nega: o tempo, o passar. ${ }^{176} \mathrm{~A}$ vingança nega o tempo, então a perspectiva metafísica sempre foi indicada pela vingança, com Nietzsche se inicia algo oposto: a afirmação do tempo. Esse sim ao tempo, seu passar e seu "foi", isso é, para Heidegger, o eterno retorno do mesmo, pois apenas afirmando o passageiro, ele se torna ao mesmo tempo o permanente, afirma-se o instante, a passagem:

\footnotetext{
75 HEIDEGGER, Quem é o Zaratustra de Nietzsche?, 101.

76 HEIDEGGER, Quem é o Zaratustra de Nietzsche?, 102.
} 
Este sim ao tempo é a vontade para a qual o passar permanece e não é depreciado num vazio. Mas como pode permanecer o passar? Somente assim, a saber, que o passar como o passar não se vá insistentemente de modo puro e simples, mas que ele sempre venha. Somente assim, a saber, que o passar e isso que nele passa retorne em seu vir como o mesmo. Esse retorno mesmo só é um permanente retorno se for um eterno retorno. Segundo a doutrina da metafísica, o predicado "eternidade" pertence ao ser do ente. ${ }^{77}$

Nesse sentido, o sim ao tempo e o "foi" é interpretado por Heidegger como o eterno retorno do mesmo, em que o passageiro, o passar tem a concepção de eternidade, de tal forma que se quer o que "foi" eternamente. Nietzsche afirma em Da redenção: "Redimir o que passou e transmutar todo 'Foi' em 'Assim eu quis!' - apenas isto seria para mim redenção."78 Essa transformação do "foi" em "assim eu quis" é interpretado por Heidegger como uma forma do ente estar no eterno retorno: "A redenção da vingança é a ultrapassagem da aversão contra o tempo para a vontade, a qual representa o ente no eterno retorno do mesmo, à medida que a vontade se torna o porta-voz do círculo"79 ou, como Heidegger afirma em O que significa pensar?: "A vontade se libera da aversão do 'foi' quando quer o retorno constante de todo 'foi'. A vontade está redimida da aversão quando quer o constante retorno do mesmo" 80 . Somente quando o ser do ente é representado como eterno retorno do mesmo, então o homem pode ultrapassar a ponte e, redimindo o espírito da vingança, ser o além-dohomem. Zaratustra é o mestre que gostaria de libertar o homem do espírito de vingança, que foi a reflexão predominante até hoje, e abrir um espaço para o sim do eterno retorno do mesmo. Para Heidegger, Zaratustra ensina, ao mesmo tempo, o eterno retorno e o além-do-homem, pois um depende do outro, dado que o além-dohomem é justamente aquele que afirma o eterno retorno e, com isso, redime o espírito de vingança ${ }^{81}$.

\footnotetext{
77 HEIDEGGER, Quem é o Zaratustra de Nietzsche?, 102, Ligeiras mudanças na tradução.

78 NIETZSCHE, Assim falou Zaratustra, 133.

79 HEIDEGGER, Quem é o Zaratustra de Nietzsche?, 102. Ligeiras mudanças na tradução.

80 HEIDEGGER, Qué significa pensar?, 69.

${ }^{81}$ Mülller-Lauter observa que antes Heidegger tinha o além-do-homem como superação do homem numa suprema figura da pura vontade de poder negando o homem até aqui, histórico. Nos anos 1950 o além-do-homem aparece como o passado negador do homo faber. Ver MÜLLER-LAUTER, Heidegger und Nietzsche, 75-76.
}

Voluntas, Santa Maria, v.12, n.1, p. 01-26, jan/abril., 2021 
Zaratustra ensina o além-do-homem e o eterno retorno, então, diante da pergunta: "quem é o Zaratustra de Nietzsche?", Heidegger responde: "ele é o mestre cuja doutrina gostaria de libertar do espírito de vingança da reflexão até hoje vigente e assim liberá-la para o sim ao eterno retorno do mesmo"82. O ensinamento do eterno retorno e além-do-homem de Zaratustra não são duas coisas separadas, mas estão juntos. Porém, o mestre sabe que o que ele ensina (eterno retorno e além-do-homem) permanece uma visão e um enigma. O que o pensador pensa não está sob jurisdição da ciência, não se prova e nem refuta, mas é algo digno de ser perguntado, e é isso que ocorre com Zaratustra, o eterno retorno e além-do-homem: " para Zaratustra, o eterno retorno do mesmo permanece, sim, uma visão, mas também um enigma"83. Zaratustra, como mestre do eterno retorno e do além-do-homem, ensina os dois juntos em um círculo que constitui o ser do ente, mas ensina como enigma. Com esse enigma se tem a ponte para a redenção do espírito de vingança em que "o pensamento até hoje vigente deve ser superado" 84

Tanto no final da preleção O que significa pensar? como do ensaio Quem é o Zaratustra de Nietzsche? Heidegger recorre à passagem do fragmento póstumo que já foi citado (FP/NF 7[54]): em Quem é o Zaratustra de Nietzsche? "Imprimir ao devir o caráter do ser: essa é a suprema vontade de poder"85 e na preleção $O$ que significa pensar?: "Que tudo retorna é a extrema aproximação de um mundo do devir ao mundo do ser." ${ }^{\prime 86}$. Com base nessas duas sentenças, Heidegger afirma que a vontade de poder "é representar o passar como permanente devir no eterno retorno do mesmo e assim fazê-lo permanente e estável." 87 Isso quer dizer que com a vontade de poder a vontade afirma o tempo (o eterno retorno). E esse pensamento toma o devir sob a guarda e proteção. Heidegger se questiona: com esse pensamento supera o espírito de vingança?

\footnotetext{
82 HEIDEGGER, Quem é o Zaratustra de Nietzsche?, 102. Ligeiras mudanças na tradução.

83 HEIDEGGER, Quem é o Zaratustra de Nietzsche?, 104.

84 HEIDEGGER, Quem é o Zaratustra de Nietzsche?, 104.

85 NIETZSCHE, Sämtlich Werke, v. 12, 312.

86 NIETZSCHE, Sämtlich Werke, v. 12, 312.

87 HEIDEGGER, Quem é o Zaratustra de Nietzsche?, 104. Ligeiras mudanças na tradução.
} 
Ou se coloca o devir no eterno retorno do mesmo, numa aversão contra o passar e, com isso, um espírito de vingança espiritualizado a mais elevada potência?

Não se trata de refutar Nietzsche, e ele próprio já deixou claro, como foi visto no aforismo 341 de A gaia ciência e o aforismo seguinte que faz a abertura de Assim falou Zaratustra. É verdade que a doutrina de Zaratustra traz a redenção da vingança, mas não como refutação em relação a Nietzsche, entretanto, deve-se notar que:

(...) de modo algum o dizemos como uma presumida refutação à filosofia de Nietzsche. Nós o dizemos, porém, para voltarmos nosso olhar para o fato, primeiro, de que também o pensamento de Nietzsche move-se no espírito do modo de pensar até hoje vigente e, segundo, em que medida e até que ponto ele aí se move. Deixamos, porém, em aberto, se este espírito do pensamento até hoje vigente é atingido em sua força norteadora, à medida que ele é interpretado como o espírito de vingança. Em todo caso, o pensamento até hoje vigente é metafísica, e o pensamento de Nietzsche, presumivelmente, realiza o seu acabamento ${ }^{88}$.

O pensamento do eterno retorno não só redime o espírito de vingança, espírito esse que é o modo de pensar até hoje vigente, mas, e também por isso, é o acabamento da metafísica. Nietzsche como o acabamento da metafísica, não significa um último ato da metafísica antes de chegar até Heidegger, pelo contrário, é Nietzsche quem indica para onde se deve ir depois do fim da metafísica. Acabar com a metafísica e redimir o espírito de vingança nos levam para o impensável: "com isso, aparece algo no pensamento de Nietzsche, que este pensamento mesmo não mais pode pensar" 89 . Nietzsche leva para algo novo, para algo impensado. A essência da metafísica não é a separação do sensível e suprassensível, embora isso lhe dê sustento. Assim, inverter a metafísica, que no fundo é inverter o platonismo, é experimentar o sensível como Dionísio, que é a inesgotável persistência do devir em que a vontade de poder quer o eterno retorno do mesmo. A oposição: "Dioniso contra o crucificado" ((FP/NF 14 [89], $\left.{ }^{1888}\right)^{90}$ significa essa inversão da metafísica em seu sentido mais profundo. Então, Zaratustra é o porta-voz de Dionísio. Com isso, Heidegger remete ao sentido do trágico,

\footnotetext{
88 HEIDEGGER, Quem é o Zaratustra de Nietzsche?, 106. Ligeiras mudanças na tradução.

89 HEIDEGGER, Quem é o Zaratustra de Nietzsche?, 106.

90 NIETZSCHE, Sämtlich Werke, v. 13, 266-267.
} 
como já abordei acima brevemente. O trágico em Nietzsche significa afirmar artisticamente toda a vida, incluindo a mais profunda dor, isso significa redimir o espírito de vingança e não ter uma vontade contra o tempo, mas estar no tempo. Heidegger afirma: “Em nenhum lugar na história da metafísica ocidental se poetizou (...) como obra de pensamento de maneira tão própria a figura essencial de seu respectivo pensador"191. Com poetizar (gedichtet) não se deve entender meramente que Nietzsche utilizou a linguagem da poesia para filosofar, mas significa mais do que isso para Heidegger. Poesia, para o autor de Ser e tempo, não é meramente um tipo de manifestação artística, mais do que isso, poesia remete à palavra grega noínoıৎ que Heidegger relaciona com produção (Herstellen), trata-se de um fazer, vir a tona, tornar efetivo a si mesmo. Por isso, Heidegger interpreta os versos de Hölderlin, também admirado por Nietzsche "... poeticamente o homem habita..." no sentido de poesia ser um construir em sentido inaugural, pois a poesia permite ao homem habitar sua própria essência. Assim, o poético aqui referido a Nietzsche é a experiência artística em geral entendida no sentido ontológico em que se pode pensar, ou seja, na poesia há uma relação entre linguagem e pensamento, sendo então possível com o poético pensar, mais precisamente, o poético é o ponto de irrupção do ser na linguagem, pois linguagem é poesia, então o pensamento do ser é o modo original do dizer poético. Como diz Benedito Nunes, "como Nietzsche, Heidegger reconhece essa fonte comum que aproxima poesia e pensamento"92. Ao dizer que com Nietzsche nunca se poetizou tanto na história da metafísica, Heidegger quer indicar que a filosofia nietzschiana ultrapassa o pensamento metafísico e coloca a possibilidade de uma nova forma de pensar diferente do que é predominante até hoje. O eterno retorno é o modo como o homem narra sua própria história no decorrer do tempo. Ora, essa narração é poéticotrágica, pois a vida se produz como o artista cria sua obra de arte.

Nietzsche indica, para Heidegger, a passagem para o poético. É claro que o pensamento nietzschiano continua sendo metafísico, logo pensa o ser como ente e o

\footnotetext{
${ }^{91}$ HEIDEGGER, Quem é o Zaratustra de Nietzsche?, 107.

92 NUNES, A passagem para o poético, 262.
} 
tempo como temporal, mas, como afirma Müller-Lauter ${ }^{93}$, a filosofia de Nietzsche como representante do fim da metafísica sinaliza para a possibilidade de transição para um novo começo que pode contar com o ser como ser. Como consequência, podemos indicar que essa concepção de tempo no eterno retorno que leva ao fim da metafísica pode fazer uma indicação para a possibilidade de pensar o tempo fora da metafísica, talvez como doação do acontecimento apropriador (Ereignis). Em suma, como novamente afirma Müller-Lauter ${ }^{94}$, na década de 1950, Heidegger não toma Nietzsche como formador do plano técnico, mas também como o antecipador da tendência contrária disso. O eterno retorno de Nietzsche representa para Heidegger a visão e o enigma para poder pensar profundamente a questão do tempo.

\section{REFERÊNCIAS}

HEIDEGGER, M. Nietzsche I. Trad.: Marco A. Casanova, Rio de Janeiro, Forense Universitária, 2010.

HEIDEGGER, M. Nietzsche II. Trad.: Marco A. Casanova, Rio de Janeiro, Forense Universitária, 2007.

HEIDEGGER, M. O que é metafísica? In: Heidegger. Trad. Ernildo Stein, São Paulo, Abril, 2005. (Coleção Os Pensadores)

HEIDEGGER, M. Qué significa pensar?. Tradução: Raúl Gabás. Madrid, Editorial Trotta, 2010.

HEIDEGGER, M. Quem é o Zaratustra de Nietzsche?. in: Ensaios e conferências. Tradução: Gilvan Fogel, Petrópolis, Editora Vozes, 2010, 91.

HEIDEGGER, M. Ser e tempo. Trad.: Fausto Castilho. Campinas-SP. Editora da Unicamp; Petrópolis-RJ. Editora Vozes, 2012.

MECA, D. S. Nietzsche ou a eternidade do tempo. Cadernos Nietzsche, São Paulo, n. 33, 2013, 181-196.

MÜLLER-LAUTER, W. Nietzsche-Interpretationen III: Heidegger und Nietzsche. Berlin; New York, De Gruyter, 2000.

\footnotetext{
${ }^{93}$ MÜLLER-LAUTER, Heidegger und Nietzsche, 23.

${ }_{94}$ MÜLLER-LAUTER, Heidegger und Nietzsche, 130.
} 
NIETZSCHE, F. Assim falou Zaratustra. Tradução: Paulo César de Souza. São Paulo: Companhia das Letras, 2011.

NIETZSCHE, F. Crepúsculo dos ídolos. Tradução: Paulo César de Souza. São Paulo: Companhia das Letras, 2006.

NIETZSCHE, F. Sämtlich Werke. Kritische Studienausgabe (KSA). Organizada por Giorgio Colli e Mazzimo Montinari. Berlim: Walter de Gruyter \& Co., 1999, 15 v.

NIETZSCHE, F. Gaia ciência. In: Obras incompletas (coleção os pensadores). São Paulo, editora nova cultura, 2005.

NUNES, B. A passagem para o poético (filosofia e poesia em Heidegger). São Paulo. Editora Ática, 1992.

\section{Contribuição de autoria}

1 - Newton Pereira Amusquivar Júnior

Mestre e Doutor em Filosofia na UNICAMP.

https://orcid.org/0000-0001-7211-9703•newtonpa@gmail.com

Contribuição: Único autor

\section{Como citar este artigo}

AMUSQUIVAR JUNIOR, N.P. A interpretação heideggeriana sobre o eterno retorno de Nietzsche e a questão do tempo. Voluntas Revista Internacional de Filosofia, Santa Maria, v. 12, n.1, e10, 2021. DOI 10.5902/2179378664488. Disponível em: https://doi.org/10.5902/2179378664488. Acesso em: dia mês abreviado. ano. 